\title{
Lipid chemistry of green macroalgae Ulva sp. a potential resource for biotechnological applications in the Southern Mediterranean Sea Coast, Alexandria shore, Egypt
}

\author{
Yasser T. A. Moustafa ${ }^{*}$ and Ahmed Moustafa M. Batran \\ Limnology department, Central Lab. for Aquaculture Research, Agricultural Research Center \\ ${ }^{*}$ Email: ymoustafaonline@yahoo.com
}

\section{ABSTRACT}

The nutritional value and chemical changes in the lipid content of the green macroalgae, Ulva sp., were assayed in the present study. Ulva samples were collected from two stations, Ras Al-Tin (station A) and El-Muntazah (Station B) along Alexandria shore on the Mediterranean Sea, in twelve sampling periods (from January to December 2012). Each three samples of each station were plotted to represent one season. The chemical characterization of the lipid fractions was performed by gas liquid chromatography. The result showed that Ulva lipid content is relatively high $(9.4 \pm 1.5$ and $12.2 \pm 2.7 \% \mathrm{DW}$, at station A and B respectively) that can be explained by the higher pollution level at the station A. The fatty acids (FAs) of Ulva sp. lipidic extract mainly composed of palmitic, oleic and linoleic FAs. Saturated fatty acids (SFAs) represented about $50 \%$ of the total FAs (TFAs). Monounsaturated fatty acids (MUFAs) accounted for a high percent, 17.6-33.4\% of TFAs. Polyunsaturated fatty acids (PUFAs) existed in a high percent in Ulva extraction reaching a maximum in winter and spring at both stations, about 38.4 and $30.5 \%$ of TFAs at station A and B, respectively. The high percent of PUFA can be attributed to the correlation between the low temperature and the degree of unsaturation. Also, the long chain fatty acids (C16 and $\mathrm{C} 18)$ constitute more than $82 \%$ of the TFAs, which are the main components for biofuel. The results indicate that Ulva has a good potential for its use in human and animal food and health maintenance as a rich source of MUFAs and PUFA as well as in biodiesel production. Also, the wide ranges of the fatty acids indicate the possibility of manipulating the fatty acids profile through the cultivation conditions.

Keywords: green macroalgae, Ulva, lipid chemistry, fatty acids profile

\section{INTRODUCTION}

Marine macroalgae are multicellular organisms with considerable potential for use as a bioactive compounds source of immense pharmaceutical value. They also show interesting nutritional characteristics because of their richness of nutritionally beneficial components such as proteins, polyunsaturated fatty acids (PUFAs), carbohydrates and antioxidants (Mohamed et al., 2011; Kumari et al., 2013a). However, the nutrient compositions of macroalgae vary depending on species, habitats, maturity and environmental conditions (Ito and Hori, 1989).

In general, macroalgae lipid content accounts for less than $5 \%$ of dry weight (DW) (Ortiz et al., 2006; Van Ginneken et al., 2011). Nevertheless, recent studies showed higher lipid content (up to $20 \%$ DW) in some green and brown macroalgae (Satpati and Pal, 2011; Rameshkumar et al., 2012).

A distinctive property of the macroalgal lipid extract is that it contains higher levels of essential polyunsaturated fatty acids (PUFAs) including $n-3$ PUFAs compared with traditional vegetables (Ortiz et al., 2006). The $n-3$ PUFAs are of 
particular importance since they cannot be synthesized by humans or fish and are thus obtained only through dietary sources (Sanchez-Machado, et al., 2004), as they may reduce the risk of heart disease, thrombosis and atherosclerosis (Van Ginneken et al., 2011; Kumari et al., 2013a). Moreover, it has also been reported that the fatty acids of certain macroalgae have antiviral activity (Johns et al., 1979). By the year 2048, macroalgae is expected to emerge as alternative resource for fish oil, the traditional source of $n$-3 PUFA (Worm et al., 2009). There is, therefore, an increasing interest in the use of edible macroalgae in the development of low-cost, highly nutritive diets for human and animal nutrition.

Fatty acid (FA) analysis has been increasingly gaining importance due to the realization of their beneficial applications in nutritional and health products. Recently, in biodiesel production, it has been shown that clean burn properties of the fuel are influenced by FA structural features including chain length and degree of unsaturation (Knothe, 2005). The author showed that, biodiesel consists of fatty acids esters, each of them affecting the properties of the fuel such as ultimately exhaust emissions, heat of combustion, cold flow, oxidative stability, viscosity, and lubricity. For instance, a long straight-chain hydrocarbon yield a high quality standard, while, a highly branched compound results poor ignition quality of the biodiesel. High quality of biofeul have been correlated with reduced nitrogen oxides (NOx) exhaust emissions, that has been reportedly increase with increasing unsaturation and decreasing chain length of the fatty acids.

Ulva spp. are the most abundant macroalaga in the coastal water of Alexandria yearly (Aleem, 1993) and represents unexplored natural resource with potential economic value for use in human and animal nutrition and as biofuel resource. Therefore, the purpose of the present study was to study the spatial and temporal variance in lipid content and its chemical characteristics in the green macroalgae Ulva.

\section{MATERIALS AND METHODS}

\section{Study Area}

Alexandria is the main harbor on the north coast of Egypt, extending about 32 $\mathrm{Km}$ along the coast of the Mediterranean Sea, at latitude $31,118836^{\circ} \mathrm{N}$ and longitude $29,551502^{\circ} \mathrm{E}$. The macroalgal samples were collected from two stations namely Ras Al-Tin (A) and Al-Muntazah (B) along $18.6 \mathrm{Km}$ distance, Alexandria coast (Fig. 1).

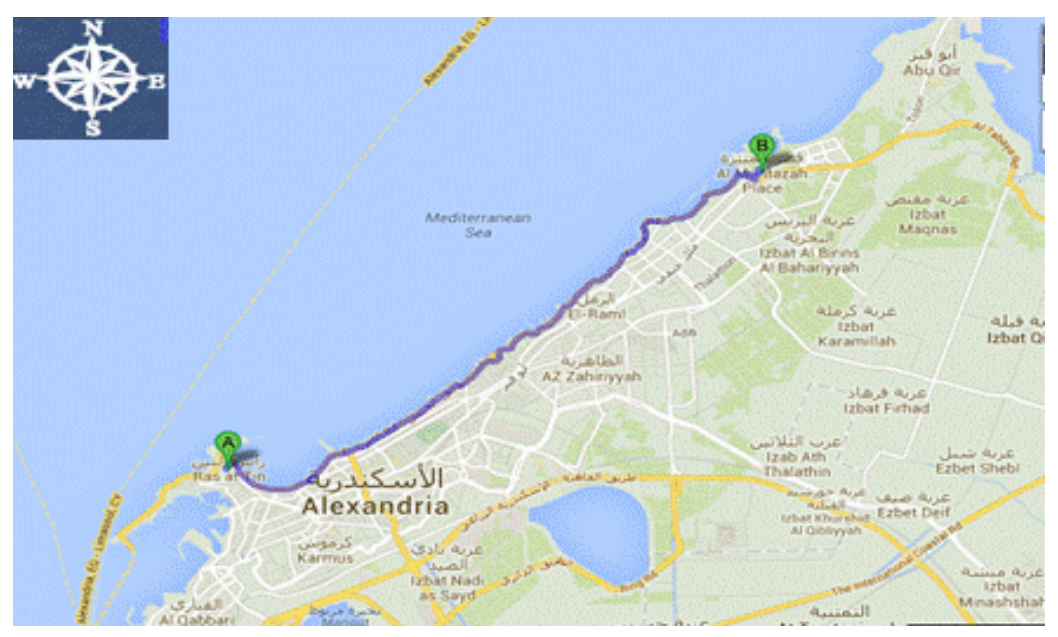

Fig. 1: Map illustrates the study stations (A and B) (from Google earth) 
The station A was selected to represent a polluted region between Eastern Harbor, one of the main Egyptian fishery grounds with an area of $2.53 \mathrm{~km}^{2}$ and an average depth of $6 \mathrm{~m}$ (El-Said and El-Sikaily, 2013) and the main Harbor of Alexandria (for export and import goods), while, station B represents unpolluted region (Al-Muntazah) as described in a previous study (El-Said and El-Sikaily, 2013). Station A can also be described to some extent as a sheltered zone while the station B is fully exposed and affected by the water current from the west to the east.

\section{Macroalgae}

The fronds were tentatively identified as Ulva fasciata (Delile 1813). Nevertheless, identification was not made to species level because of the taxonomic complications and heteromorphism that are common in these genera (Villares and carballeira, 2003). Monthly samples of the green macroalgae Ulva sp. were collected from the submerged rocks and substrates at the assigned stations and washed with seawater to remove the extraneous matters as much as possible. Then the algal samples were immediately transported to the laboratory in an ice box containing frozen gel cold packs. On arrival, the macroalgae samples were gently scrubbed under running tap water to eliminate the other species of macroalgae as well as adhering epibiota (zooplankton and young bivalves) to the algal surface, sediments and detritus, and briefly rinsed with distilled water. All cleaned algal fronds were individually blotted on towel papers to remove excess water and then dried in the drying oven on $60 \pm 2{ }^{\circ} \mathrm{C}$ for $48 \mathrm{~h}$. Then, they were pulverized in a cereal grinder for $5 \mathrm{~min}$ and sieved, using a 100 mesh sieve, to obtain a fine and homogeneous powder that was stored in hermetic sealed plastic bags in the refrigerator until lipid determination and fatty acids analysis.

\section{Total Lipid content determination}

The lipid content of the macroalgae samples was measured by solvent extraction method in a soxhlet system where petroleum ether was used as solvent (AOAC, 2000). The values are presented as percent of the dry weight (DW) of the samples.

\section{Fatty acid methyl esters (FAMEs) determination}

Lipids were extracted with a chloroform-methanol mixture $(2: 1 \mathrm{v} / \mathrm{v})$. The lipids in chloroform were dried over anhydrous sodium sulphate, and the solvent was removed by heating at $60^{\circ} \mathrm{C}$ under vacuum (AOAC, 2000). Fatty acid methyl esters (FAMEs) were prepared according to Vogel (1975). The analysis was performed in a gas liquid chromatograph equipped with dual flame ionization detector and dual channel recorder. FAMEs were separated through a coiled glass column $(1.5 \times 4 \mathrm{~mm})$ packed with Diatomite (100-120 mesh) and coated with $10 \%$ polyethylene glycol adipate (PEGA). The column oven temperature was programmed at $8^{\circ} \mathrm{C} \mathrm{min}{ }^{-1}$ from $70^{\circ} \mathrm{C}$ to $190^{\circ} \mathrm{C}$, then isothermally at $190^{\circ} \mathrm{C}$ for 25 min with nitrogen at $30 \mathrm{ml} \mathrm{min}^{-1}$. FAMEs were identified by comparing the retention times of experimental samples to those of known standards. The FAs values were represented as percent of the total FAs. The FAs analysis was conducted at the Regional Center for Food and Feed, Agricultural Research Center.

\section{RESULTS AND DISCUSSION}

\section{Total lipid content:}

The lipid content of the green macroalgae Ulva sp. ranged between 6.0 and $11.6 \% \mathrm{DW}$ with an annual average of $9.4 \pm 1.5 \% \mathrm{DW}$ at the station $\mathrm{A}$, and between 8.6 and $17.6 \% \mathrm{DW}$ with an annual average of $12.2 \pm 2.7 \% \mathrm{DW}$ at station B (Fig 2). However, no significant differences could be detected. 


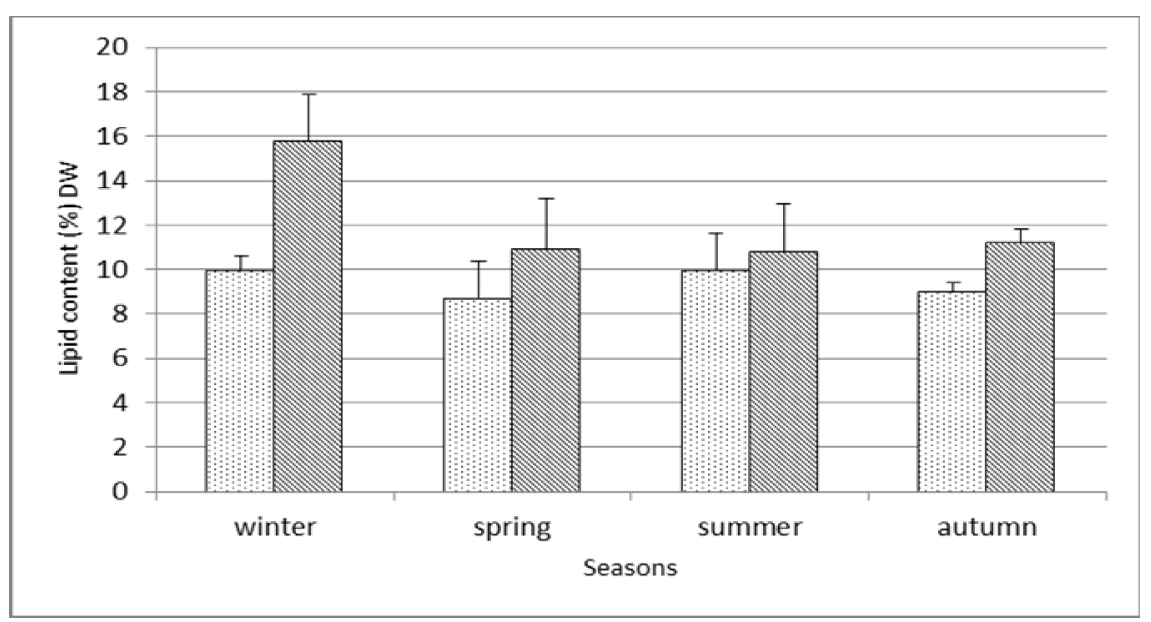

Fig. 2: Lipid content of Ulva sp.as (\%) of dry weight (DW) collected from Station A (dotted columns) and station B (lined columns), bars are SD.

In general macroalgae are reported to have lipid content less than $5 \%$ of dry weight (Van Ginneken et al., 2011; Khairy and El-Shafay, 2013; Kumari et al., 2013a). However, some macroalgae at different locations showed higher lipid content. Ulva lactuca collected from Tunisia coast has lipid content of $7.9 \%$ DW (Yaich et al., 2011). Satpati and Pal (2011) reported a total lipid content of $12 \%$ DW in Ulva rigida collected from marine coastal region of Chilka Lake, India. These high lipid contents emphasize the approach for considering macroalgae as a promising resource for production of oil-based bioproducts.

The differences in the reported quantities of extracted lipid could have been due to many factors such as geographical and seasonal factors, or climate change as well as the development stage of the macroalgae as stated by (Ortiz et al., 2006). SánchezMachado et al. (2004) recorded that, as the temperature increased, the lipid content in macroalgae decreased and remained almost stable until the end of the growing season. Similarly, the results of the present study showed a high content of lipid during winter and decrease in lipid contents from spring till autumn, particularly at station B.

The low lipid content at the station A can be explained by the pollution in that station which resulted in higher nitrogen and phosphorus contents as has been shown in a previous complementary study (Moustafa and Saeed, 2014). As the high lipid content can be used as indicator of nitrogen or phosphorus deficiency (Kumari et al., 2013b).

\section{Saturated fatty acids (SFAs) content.}

As shown in Table (1), the SFAs contents ranged from 28.21 to $79.56 \%$ of TFAs content at station A, while ranged from 17.56 to $70.98 \%$ of TFAs content at station $\mathrm{B}$, with the maximum content in autumn and the minimum content in spring at the both stations. The annual mean of the SFAs at station B, $54.7 \%$ of TFAs content, was higher than that at station A, 52.4\% of TFAs content (Table 2). These results are consistent with the findings of Yaich et al., (2011), who reported that Tunisian Ulva lactuca has SFAs in high percent (68.97\%) of the TFAs. Also, Khairy and El-Shafay (2013) reported that the SFAs are predominant in green macroalgae Ulva lactuca collected from the north coast of Egypt, during three seasons, spring, summer and autumn with a range from 70 to $75 \%$ of the TFAs. A similar percent $(70.01 \%$ of the TFAs) was reported also in Ulva reticulata by Shanmugam \& Palpandi (2008). Kumari et al. (2010) reported that SFAs in 10 species of Ulva range from 51.7 to $63.7 \%$ of TFAs. However, lower content of SFAs (33.78\% of TFAs) was reported in 
Ulva lactuca collected from the coastal area of Northern Chile (Ortiz et al., 2006). Kumari et al. (2013a) studied that the FA compositions of 12 species belonging to the order Ulvales and reported that Ulva lacutca has the highest content of SFAs 59.9\% of TFAs, while Ulva fasciata has the lowest content of SFAs $29.6 \%$ of TFAs. In general, high contents of saturated fatty acids have been reported in warm water tropical macroalgae (Bhaskar et al., 2004).

In the present study, the main component of the SFAs was also the plamitic acid (C16:0), which ranged between 23.23 and $66.9 \%$ of TFAs content at station A, and ranged between 13.48 and $43.98 \%$ of TFAs content at station $\mathrm{B}$, with the highest values in winter at station B (43.98\%) and in autumn at station A (66.91\%). Several studies reported palmitic acid as the main element of the TFAs $(52.2 \%-59.4 \%$ of the TFAs content) in Ulva lactuca collected from Alexandria coast, Egypt (Khairy and El-Shafay, 2013), and from the Northern of Tunisia (Yaich et al., 2011), and in Ulva rigida collected from marine coastal region of Chilka Lake, India (Satpati and Pal, 2011). Shanmugam \& Palpandi (2008) reported the dominance of $C 16: 0$ with a percent of $50.76 \%$ of the TFAs in Ulva reticulata.

Also a considerable percent of stearic acid (C18:0) was recorded in Ulva in the present work, ranging between 4.11 and $10.1 \%$ TFAs at station A, and from 2.73 to $24.67 \%$ TFAs at station B (Table, 1). Lower range (1.3-5.49\% of the total FAs) of stearic was reported in Ulva lacutca by Khairy and El-Shafay (2013). These long chain SFAs (C16 and C18) are of utmost importance in biodiesel industry, since they yield high quality standard and short ignition time (Knothe 2005).

\section{Content of Monounsaturated Fatty acids (MUFAs)}

The presented results in Table (1) revealed that the MUFAs, mainly omega-7 and omega-9, reached its maximum content in Ulva. sp. during spring with values of $33.39 \%$ TFAs at station A, and 30.45\% TFAs at station B. Similar percent of MUFAs (36.66 \% TFAs) was reported in Ulva lactuca by Ortiz et al. (2006). However, lower values of MUFAs were reported as maximum content of MUFAs in green macroalgae Ulva lactuca, 20.5\% TFAs (Khairy and El-Shafay 2013). Also Kumari et al. (2013a) reported MUFAs contents within a range of 5.4-12.2\% of TFAs in 12 species of Ulva.

The oleic acid accounted for the main component of MUFAs in the present work. It reached up to $30.7 \%$ of the TFAs content at station A and up to $28.69 \%$ of the TFAs content at station B. Similarly, Yaich et al. (2011) reported the FA oleic as the main component but at lower percent $(15.9 \%$ of the TFAs) in Ulva lactuca macroalgae collected in Tunisia. Ortiz et al. (2006) also reported C18:1n-9cis as the most abundant fatty acid in the Chilean Ulva lactuca, accounted for $27.42 \pm 2.60 \%$ of the TFAs content. It is worthy to mention that Ulva samples, in the present study, showed wide range of these fatty acids among locations and over time, which indicates that the environmental factors as well as spatial factor exerted an important effect on the content of these FAs in Ulva. Thus, omega- 9 and omega- 6 fatty acids showed the highest content (29.11-30.7 and 37.1-49.58\% of the TFAs content, respectively) in spring and the lowest content (7.4-12.89 and $1.05-3.72 \%$ of the TFAs content, respectively) in autumn.

The importance of MUFAs emerges from a study carried out by Huang et al. (2010) who, demonstrated that the n-6, n-7, n-9 fatty acids, such as palmitoleic acid, and oleic acid, as well as their esters exhibit strong antimicrobial activity against some oral microorganisms such as Streptococcus mutans, Candida albicans, Aggregatibacter actinomycetemcomitans, Fusobacterium nucleatum, and 
Porphyromonas gingivalis., demonstrating some specificity for individual microbial species. Wang et al. (2013) also demonstrated that Ulva lactuca contain three MUFAs derivatives, of $\mathrm{C} 18$ and $\mathrm{C} 16$ FAs, which help in resisting many pathological conditions such as cardio-diseases and cancer.

\section{Content of Polyunsaturated Fatty Acids (PUFA):}

The results in Table (1) revealed that the PUFAs maximum values were recorded in winter and spring (38.4\% of the TFAs content) at station A, and in spring (52.1\% of the TFAs content) at station B. In these occasions PUFAs showed higher values than MUFAs. During summer and autumn, MUFAs contents were higher than PUFAs at the both stations of study. Likewise, Ulva lactuca samples collected in July from north coast of Tunisia and in November from north coast of Chile and showed higher MUFAs contents than PUFAs content (Ortiz et al., 2006 and Yaich et al., 2011). Comparable PUFAs content (36.6\% of the TFAs content) was reported in Ulva rigida by Satpati and Pal (2011). Nichols et al. (1998) showed that PUFAs may be very responsive to the environmental conditions changes, as they play important roles in algal physiology. It was found that temperature changes among seasons have a major effect on the FA composition of cell membranes (Phleger, 1991). El- Shoubaky et al. (2008) reported that low temperatures result in higher de-saturated fatty acids and PUFA content.

C18-PUFA acquire special importance in human nutrition and other vertebrates which are not able to synthesis them. Similarly, (Sánchez-Machado et al. (2004) and Van Ginneken et al. (2011) reported that C18-PUFA are nutritionally important because human and vertebrate cannot build up them within their bodies. However, fish can elongate and desaturate 18:2 n-6 fatty acid (Cowey, 1976), which presented in the investigated algae (Table, 1) in substantially high amounts (up to $37.1 \%$ at station A and 49.58\% at station B). Satpati and Pal (2011) reported that among the unsaturated fatty acids 18:2 was highly observed in Indian Ulva rigida. Linoleic acid can be converted to arachidonic acid (C20:4, n-6) as reported by Simopoulos (2008).

In the present work, Ulva sp. samples contained linolenic (C18:3 $\omega-3)$, another essential fatty acid, in higher amounts (1.13-3.63 mg per g DW) than that determined in Ulva lactuca (0.13 $\mathrm{mg}$ per g DW) by Ortiz et al. (2006) and comparable to that (2.53 mg per g DW) reported in Ulva lactuca by Yaich et al. (2011).

On the other hand, PUFAs can be considered also as having an important ecological role. Alamsjah et al. (2005) have found that PUFAs of $U$. fasciata exhibit a potent algicidal activity against the red-tide phytoplankton Heterosigma akashiwo. As it has commercial importance in industries such as margarines industry. Hitherto, the margarine industry use both plants and seeds as a primary source of PUFAs (mainly C18:2 and C18:3) (Bemelmans et al., 2002).

Table 1: Seasonal variation of fatty acids content in Ulva sp. samples collected from two stations along Alexandria coast, Egypt 2012.

\begin{tabular}{|l|c|c|c|c|c|c|c|c|}
\hline & \multicolumn{4}{|c|}{ Castle station (A) } & \multicolumn{4}{c|}{ Muntazah station (B) } \\
\hline \multicolumn{1}{|c|}{ Fatty acids } & Winter & Spring & Summer & Autumn & Winter & Spring & Summer & Autumn \\
\hline & $\%$ & $\%$ & $\%$ & $\%$ & $\%$ & $\%$ & $\%$ & $\%$ \\
\hline C8:0 & - & - & - & 0.87 & 0.7 & - & 0.46 & - \\
\hline C10:0 & - & - & - & - & 1.13 & - & 0.86 & - \\
\hline C12:0 & 1.78 & - & 7.5 & 0.7 & 5.42 & 0.31 & 3.72 & 1.11 \\
\hline C14:0 & 1.34 & - & 1.33 & 1.63 & 6.98 & 0.12 & 5.66 & 1.43 \\
\hline C15:0 & - & - & 5.41 & 0.87 & 0.95 & - & 2 & - \\
\hline C15:1 $\omega 6$ & - & - & - & 0.6 & 0.22 & - & - & - \\
\hline
\end{tabular}




\begin{tabular}{|c|c|c|c|c|c|c|c|c|}
\hline C16:0 & 23.23 & 23.7 & 47.2 & 66.91 & 43.98 & 13.48 & 39.7 & 36.7 \\
\hline $\mathrm{C} 16: 1 \omega 9$ & - & - & - & 0.2 & - & 0.11 & 2.56 & 2.49 \\
\hline $\mathrm{C} 16: 1 \omega 7$ & - & - & - & - & 0.88 & 0.2 & 1 & 1.15 \\
\hline C17:0 & - & - & - & 0.2 & 0.29 & 0.2 & 1.22 & 2.39 \\
\hline $\mathrm{C} 16: 3 \omega 4$ & & & & & & & & 4.68 \\
\hline $\mathrm{C} 16: 4 \omega 3$ & - & - & - & - & - & - & 3.12 & - \\
\hline C18:ISO & - & - & - & - & - & - & - & 1.2 \\
\hline C18:0 & 4.11 & 4.51 & 10.1 & 7.32 & 9.38 & 2.73 & 6.97 & 24.67 \\
\hline 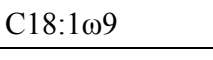 & 29.13 & 30.7 & 15.6 & 7.2 & 26.89 & 28.69 & 16.89 & 9.95 \\
\hline $\mathrm{C} 18: 1 \omega 7$ & 1.55 & 1.64 & 2.7 & 0.26 & - & 1.14 & 3.39 & 4.03 \\
\hline C18:2 $\omega 6$ & 36.81 & 37.1 & 8.28 & 0.45 & 1.8 & 49.58 & 4.7 & 3.72 \\
\hline $\mathrm{C} 18: 3 \omega 6$ & - & - & - & - & - & - & 0.36 & - \\
\hline $\mathrm{C} 18: 3 \omega 3$ & 1.56 & 1.3 & - & - & - & 2.11 & 3.57 & 2.1 \\
\hline $\mathrm{C} 18: 4 \omega 3$ & - & - & - & - & - & - & 3.3 & 0.94 \\
\hline $\mathrm{C} 20: 0$ & 0.5 & - & - & 0.46 & 0.29 & 0.48 & - & 1.97 \\
\hline $\mathrm{C} 20: 1 \omega 9$ & - & - & - & - & - & 0.31 & - & \\
\hline $\mathrm{C} 20: 1 \omega 7$ & - & - & 0.74 & 2.73 & 0.21 & - & - & \\
\hline $\mathrm{C} 20: 1 \omega 5$ & - & 1.05 & - & 9.53 & 0.88 & - & - & \\
\hline $\mathrm{C} 20: 4 \omega 3$ & - & - & - & - & - & 0.2 & - & \\
\hline $\mathrm{C} 20: 5 \omega 3$ & - & - & - & - & - & 0.2 & - & \\
\hline C22:0 & - & - & - & - & - & 0.24 & 0.5 & 1.51 \\
\hline $\mathrm{ni}^{*}$ & - & - & 1.14 & 0.07 & - & - & 0.02 & \\
\hline Total & 100.01 & 100 & 100 & 100 & 100 & 100.1 & 100 & 100.04 \\
\hline Saturated Fas & 30.96 & 28.21 & 71.54 & 79.56 & 69.34 & 17.56 & 61.09 & 70.98 \\
\hline MUFAs $^{*}$ & 30.68 & 33.39 & 19.04 & 20.52 & 29.08 & 30.45 & 23.84 & 17.62 \\
\hline PUFAs ${ }^{*}$ & 38.37 & 38.4 & 8.28 & 0.45 & 1.8 & 52.09 & 15.05 & 11.44 \\
\hline Total UFAs & 69.05 & 71.79 & 27.32 & 20.97 & 30.880 & 82.54 & 38.89 & 29.06 \\
\hline PUFA $\omega 6$ & 36.81 & 37.1 & 8.28 & 0.45 & 1.8 & 49.58 & 5.06 & 3.72 \\
\hline PUFA $\omega 3$ & 1.56 & 1.3 & 0 & 0 & 0 & 2.51 & 9.99 & 3.04 \\
\hline Ratio $\omega 6 / \omega 3$ & 23.596 & 28.538 & - & - & - & 19.753 & 0.507 & 1.224 \\
\hline PUFA/SFA & 1.239 & 1.361 & 0.111 & 0.006 & 0.026 & 2.96 & 0.246 & 0.161 \\
\hline $\mathrm{C} 16$ & 23.23 & 23.7 & 47.2 & 67.11 & 44.86 & 13.79 & 46.38 & 45.02 \\
\hline C18 & 73.16 & 75.25 & 36.68 & 15.23 & 38.07 & 84.25 & 39.18 & 46.61 \\
\hline Total C16\&C18 & 96.39 & 98.95 & 83.88 & 82.34 & 82.93 & 98.04 & 85.56 & 91.63 \\
\hline
\end{tabular}

Data are presented as \% of total fatty acids.

* MUFAS: monounsaturated fatty acids; PUFAs: polyunsaturated fatty acids; ni: not identified.

Table (2): Annual lipid content and Fatty acids compositions of macroalgae Ulva sp samples collected from two stations along Alexandria coast, Egypt 2012.

\begin{tabular}{|c|c|c|}
\hline Item & \multicolumn{2}{|c|}{ Ulva sp } \\
\hline Fatty acids $(\%)$ & Castle (Station A) & Muntazah (Station B) \\
\hline Total Lipid content & $9.4 \pm 1.5$ & $12.2 \pm 2.7$ \\
\hline Saturated FAs & 52.57 & 54.74 \\
\hline MUFAs $^{*}$ & 25.9075 & 25.2475 \\
\hline PUFAs ${ }^{*}$ & 21.38 & 20.1 \\
\hline Ratio MUFAs/PUFAs & 1.21 & 1.26 \\
\hline PUFA/SFA & 0.679 & 0.848 \\
\hline
\end{tabular}




\begin{tabular}{|l|l|r|}
\hline $\mathrm{C} 16 \& \mathrm{C} 18$ & 90.39 & 89.54
\end{tabular}

\section{Omega-6/Omega-3 ratio}

Higher omega6/omega 3 ratios were recorded in the present work than those reported and nutritionally recommended in the literatures (Table, 3). However, in two occasions comparable values were recorded at station B, 0.507 and 1.224 during summer and autumn (Table, 1). Lower ratios are reported in many species of macroalgae as represented in Table (3). As recommended by the World Health Organization, this ratio should be less than 10 in order to prevent inflammatory, cardiovascular and nervous system disorders (Sánchez-Machado et al., 2004).

Excessive amounts of omega- 6 polyunsaturated fatty acids (PUFA) and a very high omega-6/omega-3 ratio (i.e 15/1) promote the pathogenesis of many diseases, including cardiovascular disease, cancer, and inflammatory and autoimmune diseases, whereas increased levels of omega-3 PUFA (a low omega-6/omega-3 ratio, i. e. 1) exert suppressive effects (Simopoulos, 2002).

Table 3: Ratios of n-6: n-3 fatty acids in various seaweed species, as reported in earlier studies.

\begin{tabular}{|c|c|c|}
\hline Seaweed species & Ratio n-6: n-3 & Reference \\
\hline Ulva fasciata & 0.2 & Kumari et al., (2013a) \\
\hline Ulva lactuca & 0.3 & \\
\hline Ulva erecta & 0.5 & \\
\hline Ulva prolifera & 0.6 & \\
\hline Ulva lactuca & $0.17-0.29$ & Khairy and El-Shafay (2013) \\
\hline Ulva lactuca & 1.0 & Van Ginneken et al., (2011) \\
\hline Ulva tubulosa & 1.83 & Kumari et al., (2010) \\
\hline Ulva reticulata & 1.84 & \\
\hline Ulva lactuca & 3.03 & \\
\hline Ulva sp. & 2.21 & \\
\hline Gracilaria debilis & 18.8 & \\
\hline Gracilaria dura & 27.7 & \\
\hline Gracilaria furgosoni & 18.7 & \\
\hline Ulva lactuca & 1.31 & Ortiz et al., (2006) \\
\hline
\end{tabular}

Several studies attributed the variation of fatty acids in macroalgae to the environmental, and nutrients effects on quantitative fatty acid profiles, or genotypes with specific quantitative fatty acid profiles (Ortiz et al., 2006; Van Ginneken et al., 2011 ; Gosch et al., 2012\& Khairy and El-Shafay, 2013), thereby opening the possibility to optimize the fatty acid content and quality for human and animal nutrition or for oil production through specific culture conditions and selective breeding. Moreover, PUFAs and SFAs are reported in response with the area of cultivation. PUFAs content in Ulva clathrata was reported to vary from $33 \%$ to $13 \%$ of the TFAs in medium cultivation system $\left(2.25 \mathrm{~m}^{2}\right)$ and large system $\left(8000 \mathrm{~m}^{2}\right)$, respectively, while SFAs showed an opposite trend (Peña-Rodríguez et al., 2011).

\section{Content of $\mathrm{C} 16$ and $\mathrm{C} 18$ fatty acids content}

In light of increasing energy demands, predicted fossil fuels shortage in the near future, and environmental concerns such as the production of greenhouse gas carbon dioxide, emerge the importance of searching for alternative renewable and cleaner energy sources. 
Guldhe et al. (2014) reported that microalgae Scenedesmus sp., a well-known to be a potential feedstock for biodiesel production, its lipid content could be increased from $18.9-\%$ DW to $29.65 \%$ DW by using different drying methods. Also, in optimal conditions, the microalgae Desmodesmus sp. produces fatty acids characterize with high percent of $\mathrm{C} 16$ and C18 (95\% TFAs), SFAs, MUFAs and PUFAs account for $38.9 \%, 33.1 \%$ and $22.6 \%$ TFAs, respectively. This lipid quality makes it a good feedstock for biodiesel production (Ho et al., 2014). The analysis results of Ulva in the present work (Table, 1) are comparable with these quality paramters. The C16 and C18 fatty acids composed more than $82 \%$ TFAs at the both stations of the study, with the annual means of 90.4 and $89.5 \%$ TFAs at stations A and B, respectively (Table, 2). As the results in Table (1) showed that C18 FAs contents were higher than C16 FAs during spring at both stations and during winter at station A. These results are corroborated with the findings of Kumari et al. (2013a) who reported that chlorophyta spp. are characterized with higher C18 PUFAs in their lipid extraction.

The high content of $\mathrm{C} 16$ and $\mathrm{C} 18$, the main component of the biodiesel, in the lipid extraction of Ulva sp. makes this macroalgae as a potential feedstock for biodiesel production. Gosch et al. (2012) demonstrated macroalgae as a biomass source for oil-based bioproducts including biodiesel. Not only do several macroalgae have high total lipid content above $10 \%$ dry weight, but also these lipids are in the form of extractable fatty acids as the fatty acid C18:1, a predominant FA in most of them, is suitable as a biofuel feedstock. Suganya and Renganathan (2012) stated that $U$. lactuca biomass is a suitable source for the biodiesel production.

\section{CONCLUSION}

These results suggest that the green macroalgae Ulva sp. as a promising fatty acid resource for human and animal nutrition as well as for biodiesel production, due to the following features:

1-This Ulva sp. is a considerable resource for lipid even more than reported previously in literature for the other species of Ulva.

2-The main component of SFAs is pamitic acid (C16:0), fatty acids C18:1 (oleic) and C18:2 (linoleic acid) represent high percent of the TFAs in Ulva sp.

3-MUFAs and PUFAs constitute about half of the fatty acids content in this macroalgae, which are important in nutrition of human and animal, specially larval fish.

4-Likewise microalgae, Ulva sp. is rich in PUFAs, accounting for $20 \%$ of TFAs, which are boon for their utilization in both fresh and dried form in human nutrition and aquaculture.

5- $n$ - 6 fatty acids contents are higher than $\omega 3$ fatty acids contents which resulted in high $\omega 6 / \omega 3$ ratio, however, the results indicate that under suitable environmental conditions, Ulva sp. may form a promising source to enhance food quality, prevent many diseases and maintain health.

6- $\mathrm{C} 16$ and $\mathrm{C} 18$, which are the main components for biofuel, ranged from 82.3 to 98.95\% TFAs content, which suggests Ulva sp. as a good feedstock for biodiesel production.

7- It became evident that under suitable environmental conditions, the fatty acid content and quality of Ulva could be optimized for human and animal nutrition or for biodiesel production. 


\section{RECOMMENDATION}

As, in the near future, it is expected that the current available PUFAs sources will be insufficient. That necessitates new sources and strategies have to be explored, among them expansion in macroalgae cultivating systems, such as integrated multitrophic Aquaculture system (IMTA) and off-shore systems. Also the increase demand for clean energy source can be met by increase the yield of macroalgae. However, further studies are needed to determine the influence of each environmental on the FAs profile of the green macroalga Ulva spp.

\section{ACKNOWLEDGEMENT}

The authors would like to express their gratitude to Prof. Ibrahim Shaker and Prof. Safwat Abdel Ghany for reviewing the manuscript and their valuable comments.

\section{REFERENCES}

Alamsjah MA, Hirao S, Ishibashi F, Fujita Y (2005). Isolation and structure determination of algicidal compounds from Ulva fasciata. Biosci Biotechnol Biochem 69: 2186-2192.

Aleem AA (1993). The marine algae of Alexandria, Egypt, Univ. Alexandria, Alexandria, $139 \mathrm{pp}$.

AOAC (2000). Official Methods of Analysis. $17^{\text {th }}$ ed. Gaithersburg, Maryland, USA, AOAC International.

Bemelmans WJE, Broer J, Feskens EJM, Smit AJ, Muskiet FAJ, Lefrandt JD, Bom VJJ, May JF, Meyboom-de Jong B ( 2002). Effect of increased intake of $\alpha$-linolenic acid and group nutritional education on cardiovascular risk factors: The Mediterranean alpha-linolenic enriched Groningen dietary intervention (margarin) study. Am J Clin Nutr.,75:221-227.

Bhaskar N, Kinami T, Miyashita K, Park S-B, Endo Y, Fujimoto K (2004). Occurrence of conjugated polyenoic fatty acids in seaweeds from the Indian Ocean. $\mathrm{Z}$ Naturforsch., 59:310-314.

Cowey CB (1976). Use of synthetic diets and biochemical criteria in the assessment of nutrients of fish. Journal of Fish Research Board Canadian, 33:1040-1045.

El-Said GF and El-Sikaily A (2013). Chemical composition of some seaweed from

Mediterranean Sea coast, Egypt. Environ Monit Assess, 185:6089-6099.

El-Shoubaky GA, Moustafa AMY, Salem EAE (2008). Comparative phytochemical investigation of beneficial essential Fatty Acids on a variety of marine seaweeds algae. Research J Phytochemistry 2:18-26.

Gosch BJ, Magnusson M, Paul NA \& DE NYS R (2012). Total lipid and fatty acid composition of seaweeds for the selection of species for oil-based biofuel and bioproducts. Global Change B iology Bioenergy 4, 919.930.

Guldhe A, Singh B, Rawat I, Ramluckan K, Bux F (2014). Efficacy of drying and cell disruption techniques on lipid recovery from microalgae for biodiesel production. Fuel, 128: 46-52.

Ho S-H, Chang J-S, Lai Y-Y, Chen C-N N (2014). Achieving high lipid productivity of a thermotolerant microalga Desmodesmus sp. F2 by optimizing environmental factors and nutrient conditions. Bioresource Technology 156:108-116.

Huang CB, George B \& Ebersole JL (2010). Antimicrobial activity of n-6, n-7 and n-9 fatty acids and their esters for oral microorganisms Archives of Oral Biology, 55: $555-560$. 
Ito K and Hori K (1989). Seaweed: chemical composition and potential uses. Food Review International, 5: 101-144.

Johns RB, Nichols PD, \& Perry G J (1979). Fatty acid composition of ten algae from Australian waters. Phytochemistry, 18:799-802.

Khairy HM and El-Shafay SM (2013). Seasonal variations in the biochemical composition of some common seaweed species from the coast of Abu Qir Bay, Alexandria, Egypt. Oceanologia, 55(2):435-452.

Knothe G (2005). Dependence of biodiesel fuel properties on the structure of fatty acid alkyl esters, Fuel Process. Technol. 86 1059-1070.

Kumari P, Bijo AJ, Mantri VA, Reddy CRK\& JHA B (2013a). Fatty acid profiling of tropical marine macroalgae: An analysis from chemotaxonomic and nutritional perspectives. Phytochemistry, 86, 44-56.

Kumari P, Kumar M, Gupta V, Reddy CRK\& Jha B (2010). Tropical marine macroalgae as potential sources of nutritionally important PUFAs. Food Chemistry, 120, 749757.

Kumari P, Kumar M, Reddy CRK, Jha B (2013b). Algal lipids, fatty acids and sterols. Functional Ingredients from Algae for Foods and Nutraceuticals, Pages 87-134.

Mohamed S, Hashim SN, Rahman HA (2011). Seaweeds: a sustainable functional food for complementary and alternative therapy. Trends Food Sci. Technol., 23(2): 83-96.

Moustafa YTA and Saeed S M (2014) Nutritional evaluation of green macroalgae, Ulva sp. and related water nutrients in the Southern Mediterranean Sea coast, Alexandria shore, Egypt. 4th Conference of Central Laboratory for Aquacult. Res., 35-55.

Nichols PD, Virtue P, Mooney BD, Elliott NG, Yearsley GK, (1998). Seafood the good food: the oil (fat) content and composition of Australian commercial fishes, shellfishes and crustaceans, CSIRO Div. Mar. Res., Hobart, 100 pp.

Ortiz J, Romero N, Robert P, Araya J, Lopez-Hernández J, Bozzo CE, Navarrete CE, Osorio A and Rios A (2006). Dietary fiber, amino acid, fatty acid and tocopherol contents of the edible seaweeds Ulva lactuca and Durvillaea antarctica. Food Chemistry 99: 98-104.

Peña-Rodriguez A, Mawhinney TP, Ricque-Marie D \& Cruz-Suárez LE (2011). Chemical composition of cultivated seaweed Ulva clathrata (Roth) C. Agardh. Food chemistry, 129, 491-498.

Phleger CF (1991). Biochemical aspects of buoyancy in fishes, [in:] Biochemistry and molecular biology of fishes. Vol. I. Phylogenetic and biochemical perspectives, P.W. Hochachka \& T.P. Mommsen (eds.), Elsevier Sci., $\quad 209-247$.

Rameshkumar S, Ramakritinan CM, Eswaran K and Yokeshbabu M (2012). Proximate composition of some selected seaweeds from Palk bay and Gulf of Mannar, Tamilnadu, India. Asian Journal of Biomedical and Pharmaceutical Sciences, 3(16):1-5.

Sánchez-Machado DI, López-Cervantes J, López-Hernández J, Paseiro-Losado P (2004). Fatty acids, total lipid, protein and ash contents of processed edible seaweeds. Food Chem. 85: 439-444.

Satpati GG, and Pal R (2011). Biochemical composition and lipid characterization of marine green alga Ulva rigida- a nutritional approach. J. Algal Biomass Utln., 2 (4): $10-13$.

Shanmugam A, Palpandi C (2008). Biochemical composition and fatty acid profile of the green algae Ulva reticulata, Asian J. Biochem. 3 (1): 26-31.

Simopoulos AP (2002). The importance of the ratio of omega-6/omega-3 essential fatty acids. Biomedicine \& Pharmacothe-rapy 56 (8): 365-379. 
Simopoulos AP (2008). The importance of the Omega-6/Omega-3 Fatty Acid Ratio in Cardiovascular Disease and other chronic diseases. Exp. Biol. Med. 233:674-688.

Suganya T and Renganathan S (2012). Optimization and kinetic studies on algal oil extraction from marine macroalgae Ulva lactuca Bioresource Technology, 107, 319-326.

Van Ginneken VJT, Helsper JPFG, de-Visser W, van-Keulen H, Brandenburg WA (2011). Polyunsaturated fatty acids in various macroalgal species from north Atlantic and tropical seas, Lipids Health Dis., 10, 1-8.

Villares R and Carballeira A (2003). Seasonal variation in the concentrations of nutrients in two green macroalgae and nutrient levels in sediments in the Rias Baixas (NW Spain) Estuarine, Coastal and Shelf Science, 58:887-900.

Vogel AJ (1975). A textbook of practical organic chemistry, 3rd edn., Longman Group Ltd., London, $1200 \mathrm{pp}$.

Wang R, Paul VJ \& Luesch H (2013). Seaweed extracts and unsaturated fatty acid constituents from the green alga Ulva lactuca as activators of the cytoprotective Nrf2-ARE pathway. Free Radical Biology and Medicine, 57, 141-153.

Worm B, Hilborn R, Baum JK, Branch TA, Collie JS, Costello C, Fogarty MJ, Fulton EA, Hutchings JA, Jennings S, Jensen OP, Lotze HK, Mace PM, McClanahan TR, Minto C, Palumbi SR, Parma AM, Ricard D, Rosenberg AA, Watson R, Zeller D (2009). Rebuilding Global Fisheries. Science.;325:578-585.

Yaich H, Garna H, Besbes S, Paquot M, Blecker C and Attia H (2011). Chemical composition and functional properties of Ulva lactuca macroalgae collected in Tunisia. Food Chemistry, 128: 895-901.

\section{ARABIC SUMMARY}

$$
\begin{aligned}
& \text { كيمياء الدهون فى الطحلب الأخضر من نوع الأولفا: كمصدر محتمل للتطبيقات البيوتكنولوجيه من الساحل }
\end{aligned}
$$

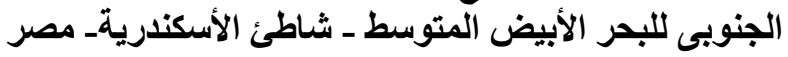

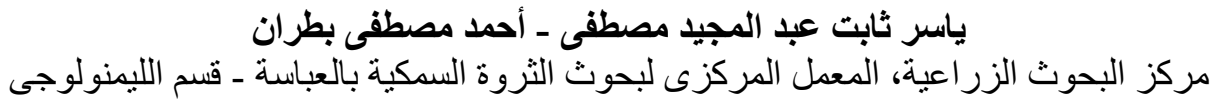

